\title{
OVERVIEW THE SEVEN STARS RATING IN HOTEL INDUSTRY
}

\author{
Agung Gita Subakti \\ Hotel Management Department, Faculty of Economic and Communication, BINUS University \\ Jln. K.H. Syahdan No. 9, Palmerah, Jakarta Barat 11480
}

\begin{abstract}
Picking the right hotel can be tricky especially in today's world of multiple rating systems. A luxury hotel rating once topped out at five stars but in the war to snag vacationers certain hotels that sing tunes of opulence and luxurious pleasure have started to accumulate seven stars. Star rating systems vary from continent to continent, country to country, and in a country. Hotel ratings have become a subjective assessment of amenities depending on the hotel and location. But the big question that is how they rate a seven stars Hotel. What makes it different from five stars Hotel or any fine establishment alike. In this case, the author is over viewing some of the Hotels in the world that are known for its seven stars reputation and taking a closer look on how they get their reputation for being the most luxurious Hotels in the world
\end{abstract}

Keywords: hotel, star rating systems, seven stars

\begin{abstract}
Memilih hotel yang tepat bisa menjadi hal yang rumit, terutama dalam sistem dunia rating sekarang ini. Rating sebuah hotel mewah dahulu ada pada bintang lima, tetapi dalam perang untuk merebut rombongan turis, hotel-hotel tertentu yang menyajikan kemewahan dan kesenangan telah mulai untuk mengumpulkan bintang tujuh. Sistem rating hotel berbintang bervariasi, dari benua ke benua, negara ke negara, dan di suatu negara. Peringkat Hotel adalah penilaian subjektif terhadap fasilitas, tergantung pada hotel dan lokasi. Akan tetapi, pertanyaan besar itu adalah bagaimana mereka menilai sebuah hotel bintang tujuh. Hal apa yang membuatnya berbeda dari hotel bintang lima, atau serupa dalam hal apa. Dalam hal ini, penulis mengulas beberapa Hotel di dunia yang dikenal reputasinya sebagai hotel bintang tujuh dan melihat lebih dekat tentang cara mereka mendapatkan reputasi mereka untuk menjadi hotel yang termewah di dunia.
\end{abstract}

Kata kunci: hotel, sistem penilaian bintang, tujuh bintang 


\section{INTRODUCTION}

The Hotel industry is a part of Hospitality industry. Hospitality comes from the French word "hospice," meaning to take care of those traveling and provide for the weary. The history of this industry is long as hospitality providers have been around at least as early as 40 B.C. Hospitality has changed dramatically through the years in response to influences such as wars, economic fluctuations and social changes. The earliest record of the hospitality industry lies with the Romans. Roman men traveled for business and were the first to travel for leisure as well. Once the Roman Empire fell, much of the hospitality industry fell to religious orders such as monasteries who welcomed travelers. With the increased use of the stage coach, English travelers stayed in inns, which were actually private homes that provided a room and meal.

Nowadays, the Hotel Industry are growing much more that it is used to be in the past centuries, they were developing not just as a place for travelers to eat, drinks, and sleep but it became more than that, we have aware that the concept of Hotel is "A hotel as an establishment providing for reward accommodation, food and drink, for travelers and temporary residents and are usually also meals and refreshment and sometimes other facilities for other user" (S Medlik, 2000) and in other definition stated that "Primarily and fundamentally a hotel is an establishment which provides board and lodging, not engaged in interstate commerce, competitive with or affecting interstate commerce (or so related thereto that the regulation of the one involves the control of the other), but is a quasidomestic institution retaining from its ancient origin certain traditional, and acquiring, in its modern development, certain statutory rights and obligations to the public where all persons, not disqualified by condition or conduct, prepared to pay for their accommodation, are to be received and furnished with a room or place to sleep or occupy if such accommodations are available, and with such services and attention as are incident to their use of the hotel as a home, and/or with food, at stipulated prices, and with or without contract as to duration of visit, and which conducts, within the confines of its physical locations, this business of supplying personal services of individuals for profit. Incidental to such fundamental and principal business, the hotel may furnish quarters and facilities for the assemblage of people for social, business or entertainment purposes, and may engage in renting portions of its premises for shops and business whose contiguity is deemed appropriate to an hotel" (Kainthola, 2009) but savvy travellers need more than just a place to stay whenever they were travelling across the continent, what they need is a place that give experiences. a place that provide a state of the art technologies, an unnusual design, a new definition of ambience, a high level of services, an extraordinary selection of food with high quality ingredients prepared by a world michelin star holder chef, etc

One method of evaluating hotel quality is the creation of a ranking based on specific criteria and on the assignment of a symbol that certifies a quality category. The symbol and the scale used can vary from one country to another but the most commonly used are the star and the diamond, with a scale of 1 to 5. (Robert Minazzi, 2010)

\section{Hotel Classification Systems}

Early hotels and inns were little more than an available bed and something barely palatable to eat. The emergence of tourism in the latter half of the $19^{\text {th }}$ century brought with it an improvement of the standards of the early inns. Some pressure was placed on these facilities to offer some minimum standards where the consumer was able to identify a property with specific amenities. The rating system emerged out of efforts by the Automobile and cycling clubs in Europe, who in their tour books displayed hotels, which they recommended to their membership, based on the guaranteed facilities which these hotels/inns offered. This led to the establishment of rating systems such as the Automobile Association (AA) and its American counterpart the (AAA) and the Michellin tyre company's Michellin Red Guide and other mobile guides. 
After World War II National Tourist Boards began to consider some form of hotel registration/classification system. There was some difficulty in doing so. By 1970 only five European countries had national classification systems, by 1980 this number increased to 22 European countries and 60 countries worldwide. The criteria applied by the classification systems were, and still are not uniformed. There were various meanings attached to registration, classification and grading.

Registration: form of licensing which, may or may not demand a minimum standard. Signifies some conformation with health fire safety legislation. Implies a minimum criteria.

Classification: separation of different types and ranges of accommodation into several categories based on a range of criteria. Hotel accommodations can allow for five to seven categories to be applied. - Other forms of accommodation e.g. motels, guesthouses and self catering apartments seldom justify more than two or three classes.

Grading: often combine with classification, this is a quality assessment awarding a symbol to denote an above average service to an accommodation facility. E.g Green globe classification systems for environment

\section{Popular Classification Systems}

Official Hotel and Resort Guide (OHRG) Travel Industry classification system ratings are deemed as being comparable around the world, making it easier for professionals in the travel trade. Ten Quality levels which can be divided as follows Deluxe: Super Deluxe, Deluxe, Moderate Deluxe, First Class Superior First Class, First Class, Limited Service First Class, Moderate First class Tourist Superior tourist class, tourist class, moderate tourist class

These rating combine two elements: (1) Quality of quest accommodations a. room size, quality of furnishings; (2) Extent of hotel facilities a. Number and size of public rooms and meeting facilities.

AA rating system (British System) this system focuses on a consumer's perspective on accommodation properties. The objective was to introduce a classification system easily understood by the consumer. This system is part of the description of properties seen in travel books. The American version is the AAA system.

\section{Minimum Requirements for AA Recognition}

One Star Hotels Hotels in this classification are likely to be small and independently owned, with a family atmosphere. Services may be provided by the owner and family on an informal basis. There may be a limited range of facilities and meals may be fairly simple. Lunch, for example, may not be served. Some bedrooms may not have en suite bath/shower rooms. Maintenance, cleanliness and comfort should, however, always be of an acceptable standard.

Two Star Hotels In this classification hotels will typically be small to medium sized and offer more extensive facilities than at the one star level. Some business hotels come into the two star classification and guests can expect comfortable, well equipped, overnight accommodation, usually with an en-suite bath/shower room. Reception and other staff will aim for a more professional presentation than at the one star level, and offer a wider range of straightforward services, including food and drink.

Three Star Hotels At this level, hotels are usually of a size to support higher staffing levels, and a significantly greater quality and range of facilities than at the lower star classifications. 
Reception and the other public rooms will be more spacious and the restaurant will normally also cater for nonresidents. All bedrooms will have fully en suite bath and shower rooms and offer a good standard of comfort and equipment, such as a hair dryer, direct dial telephone, toiletries in the bathroom. Some room service can be expected, and some provision for business travelers.

Four Star Hotels Expectations at this level include a degree of luxury as well as quality in the furnishings, decor and equipment, in every area of the hotel. Bedrooms will also usually offer more space than at the lower star levels, and well designed, coordinated furnishings and decor. The en-suite bathrooms will have both bath and fixed shower. There will be a high enough ratio of staff to guests to provide services like porterage, 24-hour room service, laundry and dry-cleaning. The restaurant will demonstrate a serious approach to its cuisine.

Five Star Hotels Here you should find spacious and luxurious accommodation throughout the hotel, matching the best international standards. Interior design should impress with its quality and attention to detail, comfort and elegance. Furnishings should be immaculate. Services should be formal, well supervised and flawless in attention to guests' needs, without being intrusive. The restaurant will demonstrate a high level of technical skill, producing dishes to the highest international standards. Staff will be knowledgeable, helpful, well versed in all aspects of customer care, combining efficiency with courtesy.

Red Star Awards AA star classifications are usually depicted in black on signs and in the AA's guides and electronic products. However, at each of the five classification levels, the AA recognizes exceptional quality of accommodation and hospitality by awarding Red Stars for excellence. A hotel with Red Stars, therefore, has been judged to be the best in its star classification and recognizes that the hotel offers outstanding levels of comfort, hospitality and customer care.

Country House Hotels Country House Hotels offer a relaxed, informal atmosphere, with an emphasis on personal welcome. They are usually, but not always, in a secluded or rural setting and should offer peace and quiet regardless of location.

Town House Accommodation This classification denotes small, personally run hotels which afford a high degree of privacy, concentrate on luxuriously furnished bedrooms and suites, with highquality room service rather than the public rooms or formal dining rooms usually associated with hotels, but they are usually in areas well served by restaurants. All fall within the Four or Five Star classification.

Travel Accommodation (Lodges) This classification denotes budget accommodation, suitable for an overnight stay usually in purpose-built units close to main roads and motorways, often forming part of motorway service areas. They provide consistent levels of accommodation and service, matching today's expectations.

Guesthouse/Private Hotels The term guest-house can lead to some confusion, particularly when many include the word hotel in their name. For AA purposes, small and private hotels are included in this category when they cannot offer all the services required for the AA hotel star rating system. The term does not imply that guesthouses are inferior to hotels, just that they are different. Many, indeed, offer a very high standard of accommodation. It is not unusual to be offered en suite bathrooms, for instance, or to find a direct-dial telephone and a colour television in your room. Some guest-houses offer bed and breakfast only, so guests must go out for the evening meal. These facilities should state clearly if there are any restrictions to your access to the house, and whether they offer any meals. This should be communicated to the customer when booking. 
Farmhouse Farmhouse accommodation is particularly noted for being relatively inexpensive and cosy, with good home-cooking where appropriate. Some are working farms, Guest are at times allowed to participate or view farm activities, there are cases where guest accommodation is run as a separate concern from the farm, and visitors are discouraged from venturing on to the working land. Standards will vary considerably, Some of farmhouses are grand ex-manor houses furnished with antiques and offering a stylish way of life, whereas others offer more simply furnished accommodation, and in others guests may have to share the family bathroom and sitting/dining room.

Pubs and Inns We all know what we can expect to find in a traditional inn a cosy bar, a convivial atmosphere, decent beer and pub food. Nevertheless, there are a few extra criteria which must be met for the AA classification: breakfast is a must, in a suitable breakfast room, and the inn should also serve at least light meals during licensing hours. A number of small, fully licensed hotels are classified as inns, and the character of the properties will vary according to whether they are traditional country inns or larger establishments in towns.

AA Rosette Awards The AA makes annual rosette awards on a rising scale of one to five for the quality of food served in restaurants and hotel restaurants. Only those offering the highest international standards of cuisine and service will merit the AA's top awards of four or five rosettes.

\section{Outstanding Quality (5 and 4 Rosettes)}

Five rosettes is the supreme accolade, made to chefs at the very top of their profession. This award recognizes superlative standards of cuisine at an international level, evident at every visit in every element of the meal. Creativity, skill and attention to detail will produce dishes cooked to perfection, with intense, exciting flavours in harmonious combinations and faultless presentation. Menus may be innovative or classical, and may use luxury ingredients like lobster, truffles, foie gras, etc. often in unexpected combinations and with secret ingredients that add an extra dimension of taste and interest. At this level, cuisine should be innovative, daring, highly accomplished and achieve a noteworthy standard of consistency, accuracy and flair throughout all the elements of the meal. Excitement, vibrancy and superb technical skill will be the keynotes.

\section{High Quality}

Only cooking of the highest national standard receives three or more rosettes. Menus will be imaginative; dishes should be accurately cooked, demonstrate well developed technical skills and a high degree of flair in their composition. Ingredients will be first-class, usually from a range of specialist suppliers, including local produce only if its quality is excellent. Most items - breads, pastries, pasta, petits fours - will be made in the kitchens, but if any are bought in, for example, breads, the quality will be excellent.

\section{Good Quality (2 and 1 Rosettes)}

Two rosettes denote cooking that displays a high degree of competence on the part of the chef. The menus should include some imaginative dishes, making use of very good raw ingredients, as well as some tried and tested favourites. Flavours should be well balanced and complement or contrast with one another, not over-dominate.

One rosette denotes simple, carefully prepared food, based on good quality, fresh ingredients, cooked in such a way as to emphasize honest flavours. Sauces and desserts will be home-made and the cooking will equate to first-class home cooking. (Organization, 2002) 


\section{The Seven Stars Reputation Hotels}

\section{Burj Al Arab, Dubai U.A.E}

This is said to be the first seven stars hotel in the world, made as The icon of Dubai, Burj Al Arab rises out of its own man-made island 280 meters from the Jumeirah coast, $15 \mathrm{~km}$ south of the city and 25km from Dubai International Airport. Visible from almost everywhere in the city, it is linked to the shore by a slender, gently curving causeway.

Height At 321 meters above sea level, Burj Al Arab is the tallest all-suite hotel in the world. It stands proud as one of the tallest buildings in the world and the tallest single structure on a manmade island. Burj Al Arab 's island was built far out enough to ensure that the shadow of the hot el 's silhouette does not fall on the other Jumeirah properties on the mainland. It is a mere 60 meters shorter than the Empire State Building.

Structure An incredible 70,000 cubic metres of concrete and more than 9,000 tons of steel were employed in the construction of the tower. The Island Burj Al Arab stands on a man-made island 280 metres offshore, connected to the mainland by a slender, gently curving causeway. 250 Foundation piles have been driven 40 metres deep into the seabed to secure the island. Glass 43,446 square metres of glass panels were used for the exterior of Burj Al Arab.

The Ellipse Fountain 20,000 litres of water, combined with bursts of fire, are orchestrated into the most unique and dramatic visual symphony at the entrance of the iconic hotel. This taming of the elements has never been achieved anywhere else in the world and was recently developed by Wet Design.

Fire Display Fireballs 2.5 metres in diameter are propelled eight meters into the air from each of the four towers, created by releasing a controlled amount of non-toxic propane gas. The result is a spectacular optical illusion, with the flames reflecting in the hotel's glass exterior.

The exclusive Burj Al Arab is an all-suite hotel that encompasses 28 double stories to contain the 202 luxury duplexes of superior standard. The unrivalled personalized service is a signature of Burj Al Arab. For the comfort and convenience of guests, there is a dedicated reception on each floor with check-in conducted in the privacy of the individual suite. Butlers are in attendance 24 hours a day to address the needs of each and every guest. There are over 1,600 colleagues from 75 countries working in Burj Al Arab, which makes the staff-to-suite ratio 8:1. It is one of the highest in the world, and ensures personalized service and continuous care and pampering. Special facilities for younger guests are available: Sinbad's Kids' Club is located on the $18^{\text {th }}$ floor, where children are looked after, play games and enjoy entertainment. In-suite babysitters can be arranged on request.

Room Specifications The collection of duplex suites ranges from 170 square metres $(1,830$ square feet) to an incredible 780 square metres (8,396 square feet): 142 One Bedroom Deluxe Suites, 18 Panoramic Suites, 4 Club Suites, 28 Two Bedroom Deluxe Suites, 6 Diplomatic Suites, 2 Presidential Suites, 2 Royal Suites.

Features In-suite technology is intuitive and programmed to suit the needs of every discerning guest. It includes 93 cable television channels, 2 in-house television channels, a vast array of DVDs screened on 42" plasma screens with surround sound, a business desk with laptop, scanner, complimentary broadband wireless internet connection and private facsimile. All in-suite laptops of Burj Al Arab are equipped with the latest software including Windows Vista and Microsoft Office 2007. Floor to ceiling windows offer each guest their own breathtaking view of the Arabian Gulf and curtains are electronically controlled. In fact, the entire in-suite electronic system is designed to allow 
guests to fine tune their environment at the touch of a button. Every suite benefits from a range of unique first-class flourishes, including an extensive selection of complimentary Hermes amenities and a pillow menu with 17 options, including some for children. A special bath menu is available and the butler will be glad to explain different options: from the refreshing Mint Bath to the most decadent Extreme Indulgence which includes caviar, champagne and strawberries. Aromatherapy Associates' products are used in preparing the special baths. A sophisticated private dining menu is served 24 hours. Alternatively, guests are able to coordinate with the Executive Chef and Private Dining Manager to create a personalized menu for a romantic dinner or a party which will be served in the intimate opulence of a private suite.

\section{Restaurants and Bars}

- Al Mahara ('Oyster Shell', accessible from the upper lobby) Recognised as one of the finest restaurants in the world

- $\quad$ Al Muntaha ('The Highest' or 'The Ultimate', located on the 27th floor)

- $\quad$ Al Iwan ('Royal Dining Hall', located in the upper lobby)

- $\quad$ Junsui ('Pure', located on the ground Mezzanine floor) The Japanese word for 'pure', Junsui is a new authentic Asian restaurant set within the opulent interiors of Burj Al Arab,

- $\quad$ Bab Al Yam ('Gateway to the Sea', located on the ground floor) Bab Al Yam offers brasseriestyle informality wrapped in sensational sea views and tranquility

- $\quad$ Majlis Al Bahar ('Beachside Lounge', located at Burj Al Arab 's private beach )

- $\quad$ Sahn Eddar ('Reception of the House', located in the upper lobby) An iconic spot to meet at the base of the world's tallest atrium, Sahn Eddar is a symphony of classical sounds, marble, mosaic and soft torch lighting. Against the backdrop of the magnificent 42 metre water display

- $\quad$ Skyview Bar (adjacent to Al Muntaha, located on the 27th floor) (Jumeirah)

\section{The Seven Stars Galleria Milano, Milan Italy}

The Seven Stars Galleria hotel is a unique and prestigious property, intimate and exclusive, assuring the highest level of service. Each room is catered to by a professional butler. Seven Stars Galleria is a symbol of elegance and has the honour of being the only hotel to be located inside the historical "Galleria Vittorio Emanuele II" built in 1876. The architectural features of this historical land-mark, like the hand painted vaulted ceilings and large shuttered windows, have been preserved to provide guests with a unique environment. The tasteful blend between the contemporary and traditional style of the décor contribute to the unparalleled ambience provided. This stunning new hotel is a precious jewel in the crown of Italy's fashion city.

Seven Stars Galleria boasts a truly exclusive and quiet ambiance, thanks to its limited amount of guest rooms. With only 7 suites, each has been sumptuously styled and equipped with all the latest in amenities, such as LCD televisions and satellite programming. Spacious rooms with cream-coloured walls and beautiful crown moulding help create a stylish environment of rest and relaxation. Furthermore, each rooms includes butler service, raising the bar in comfort and service standards for the whole country. The hotel's à la carte lounge restaurant offers a fully licensed bar and in-room dining 24 hours a day. La Sinfonia Restaurant's menu varies seasonally whilst the chef creates a different gourmet menu every day. The intimate restaurant is open from early morning till evening offering Continental, Italian and Nouveau cuisine all accompanied by an extensive choice of Italy's finest wines.

Occupying the second floor of the world famous Galleria Vittorio Emanuelle II, this stunning new hotel is a precious jewel in the crown of Italy's fashion city and prides itself on being surrounded by the most elite shopping temples of the city such as Prada, Gucci and Dolce \& Gabbana, not to mention the trendiest and most exclusive restaurants of the city. Not only that, but it overlooks the 
Duomo Cathedral and the La Scala Opera House, making it one of the most prestigious addresses in the city.

(Sevenstars Galleria Milano)

\section{Emirates Palace, Abu Dhabi UAE}

The building was designed by renowned architect, John Elliott RIBA, who was Senior Vice President at Wimberly, Allison, Tong and Goo, an international firm specialising in Luxury Hotels. It opened in November 2005 but certain restaurants and spas did not open until 2006. The hotel was built by and is owned by the Abu Dhabi government, and is currently managed by the Kempinski Group. The costs to build the hotel were 1.9 billion GBP or 11.02 billion AED. The Emirates Palace occupies $850,000 \mathrm{~m}^{2}$ of floor space. Underground parking allows housing for 2,500 vehicles. There are two swimming pools and spas. The hotel has its own marina and helipad. The Emirates Palace is the second most expensive hotel ever built, only surpassed by Marina Bay Sands in Singapore.

Emirates Palace, located on $1.3 \mathrm{~km}$ of private white sandy beach and surrounded by 85 hectares of beautifully landscaped gardens, with 114 domes that are 80 meters high. It is only 30 min drive from Abu Dhabi airport and 1.5 hours drive from Dubai airport.

Many of the suites offered are furnished in gold and marble. The main central area houses an expansive marble floor, balconies and a large patterned dome above, picked out in gold. The topmost floor has six Rulers' Suites which are reserved solely for Emirati royalty and dignitaries. ${ }^{[1]}$ The hotel also contains a large conference centre. In December 2010, it boasted the world's most expensive Christmas tree, valued at over 11 million dollars.

Overall, the hotel has 302 rooms and 92 suites. But, the hotel has 16 Palace Suites on the sixth and seventh floors. 22 three-bedroom suites are reserved for hosting Heads of State or Government, recently for example, Prime Minister Tony Blair and Chancellor Angela Merkel. The cost of staying begins at $\$ 400$ per night for the Coral Room (floor space of 592 square feet) in the low season; and The Palace Grand Suite (7319 square feet) is the most expensive at $\$ 11,500$ per night.

Set in over 100 hectares of landscaped gardens, Emirates Palace offers $1.3 \mathrm{~km}$ of exclusive beach, two swimming pools, one designed for adventure and one for relaxation, tennis courts, cricket, a rugby pitch and soccer facilities, fitness suites and a spa, besides water sports.

- It approximately costed 3 billion USD to build the property in 3 years with 20,000 workers, designed by Wimberley Allison Tong \& Goo of the United Kingdom

- $\quad 1 \mathrm{~km}$ from wing to wing, 100 hectares total area.

- $\quad 1.3 \mathrm{~km}$ private beach.

- $\quad 394$ rooms and suites, ranging from 55 sqm to 680 sqm.

- $\quad 40$ meeting and conference rooms.

- $\quad$ Ballroom with a guest capacity of 2400 theatre style.

- $\quad$ Auditorium with seated guest capacity of 1100.

- 619 plasma and LCD screens in guest rooms and meeting rooms.

- $\quad 5 \mathrm{~kg}$ of pure edible gold is used per year for decoration mainly on deserts.

- $\quad 128$ kitchens and pantries.

- $\quad 200$ tonnes of oranges squeezed for fresh juice every year.

- $\quad 6.4 \mathrm{~km}$ jogging trail.

- $\quad 114$ domes, with the Central Dome at a height of 72.6 metres above ground.

- 8 escalators and 102 elevators, with a maximum capacity up to 55 persons per elevator.

- $\quad$ Marble imported from 13 countries across the world.

- $\quad 12$ external fountains and 8 indoor water features.

- 1002 chandeliers, the largest weighing 2.5 tonnes.

- 8000 trees set in landscaped gardens. 
- $\quad 2$ wall display carpets, handmade in Thailand, weighing 1 tonne each.

- 818 parking spaces.

- $\quad$ Daily laundry capacity of 6 tonnes.

- 1200 employees from 58 different countries.

- $\quad$ Emirates Palace offers the world's most expensive one million dollar tailor made suite holiday. (Emirates Palace Abu Dhabi)

\section{What Makes Seven Stars Hotel Different?}

Hotels, like restaurants, movies and TV shows, are classified by a star rating. Hotels are usually rated based on the quality of the food, the location, accessibility, room sizes, amenities, view and the availability and quality of fitness centers and spa. So far, there has not been a uniform hotel ranking guide, which is why different standards are set per country.

Five star hotels are luxury hotels and mostly cater to celebrities, high ranking political figures and business moguls. Most of the time, business executives stay at five star hotels when they are on a business trip and meeting with other investors. On the other hand, a seven star hotel caters to royalty and billionaires (and their heirs) with lots of money to spend. Rich business executives stay in seven star hotels but their stay may not be connected to business. Seven star hotels are generally chosen for leisure stays.

Luxury hotels or five star hotels are constructed from high-grade materials and have intricate architectural designs. Mostly, 24-hour room service is available, aside from gourmet dining and a high staff-to-guest ratio. Rooms are huge and are decorated with fine furnishings. The rooms have luxury bath products and toiletries, high-speed Internet access and DVD players. Most five star hotels have access to a golf course; spa and wellness center; pool and tennis courts. The most luxurious room in a five star hotel is the presidential suite.

Though a Five star hotel seems to have everything a person want to feel luxurious, a seven star hotel tops this. They have such services as a Rolls Royce Limousine guest shuttle service, a royal suite rather than a presidential one and gold furnishing. On average, the cheapest room for two in a seven star hotel is at $\$ 1700$ per night, this will get you and a companion to a deluxe five star hotel room for three nights, for instance, Burj Al Arab has a 780 square meters royal suite with a rate of $\$ 28.000$ per person per night, the hotel has a magnificent gold and marble staircases, mahogany furniture, master bedrooms with rotating four poster canopy, Hermes body products and a Rolls Royce, BMW or helicopter transfer or service.

Staffs at seven star hotels research their incoming guests. Because of this, guests are known by everyone working in the hotel, making the stay more memorable. Five star hotel staffs are not required to research the guest mainly because it is not part of what you are paying them for and also the fact that they receive a greater number of guests and reservations. Additionally, the rates at seven star hotels are higher so it is no surprise that staff would pay significantly more attention to their guest

\section{CONCLUSION}

The seven stars rating hotels were simply a reputation given by the media and the customer who have experiencing them. There are no such things as the proper rating or classification given by hotel association concerning on how the seven stars hotel should look like in terms of facilities, state of the art technology, etc. A seven star hotel is considered a synonym for grandeur, class and style. Offering luxuries like limousine service, private transfer for all guests via private golf cart, private 
butler service and just about anything else that is being associated with vanity. These days, savvy and wealthy globetrotters, demand for caviar, personal butlers and Bentley and more tasty accommodation morsels as they prefer to travel (and rest) in style when it comes to bedding heads for the night. Seven star hotels accomplish all this. However, the seven stars hotels means that the Hotel had pass the five star standard rating given by Hotel association. It gives more than just a service, but experience that customers will not find in any five star deluxe hotels, the guest are pampered with luxury and a very personalized service. And at the end the price tag is worth the service. Finally, it is a matter of how the seven stars Hotels can compete to exceed customer expectation and to gain the reputations as the best hotel in the world.

\section{REFERENCES}

Jumeirah. Retrieved February 5, 2012, from Jumeirah: http://www.jumeirah.com/en/Hotels-andResorts/Destinations/Dubai/Burj-Al-Arab/

Kainthola, V. P. (2009). Principles of Hotel Management. Delhi: Global Media.

Kempinski. Retrieved February 5, 2012, from Emirates Palace Abu Dhabi: http://www.kempinski.com/en/abudhabi/Pages/Welcome.aspx

Sevenstars Galleria MIlano. Retrieved February 5, 2012, from Sevenstars Galleria Milano: http://www.sevenstarsgalleria.com/

Organization, R. D. (2002). Hotel Classification Systems. Retrieved February 5, 2012, from http://www.onecaribbean.org/content/files/hotelcalssification(1).pdf

Robert Minazzi, P. (2010). Hotel Classification Systems: A Comparison of International Case Studies, 64-86. International Journal of Tourism Research n. 2: 135-147

S Medlik, H. I. (2000). The Business of Hotel Fourth Edition. Oxford: Butterworth-Heinemann Elsevier. 